\title{
Deleterious IKZF1 Gene Mutation
}

National Cancer Institute

\section{Source}

National Cancer Institute. Deleterious IKZF1 Gene Mutation. NCI Thesaurus. Code C150496.

A change in the nucleotide sequence of the IKZF1 gene that is associated with increased risk of disease. 